\title{
PREVALENCE AND INTENSITY OF HELMINTH PARASITES IN MYSTUS TENGARA
}

\author{
Aleya Begum, Subrina Sehrin ${ }^{1}$, Yasmin Sultana \\ and Nurul Arefin MaHMOOD \\ Department of Zoology, University of Dhaka, Dhaka-1000, Bangladesh
}

Key words: Mystus tengara, Helminth parasites, Prevalence, Intensity

Among fresh water fishes, cat fishes are important in Bangladesh. Cat fish the 'Tengra' (Mystus sp.) is an easy source of protein. Parasites can weaken a fish by destroying tissue, removing blood and cellular fluids, diverting part of its nutrient supply and sometimes develop secondary infections ${ }^{(1)}$. Therefore, the host-parasite relationship is an important factor to understand the load and the pattern of parasitic distribution.

In Bangladesh, a few works have been done on the parasite of Mystus tengara. Bashirullah make a brief survey on the helminth fauna of certain marine and fresh water fishes of Bangladesh (2). Ahmed(3) studied some helminth fauna of Mystus sp. Begum and Chandra $^{(4)}$ investigated the monogenetic trematode of $M$. vittatus. Vankara and Vijaylakshmi(5) also worked on the metazoan parasites of M. vittatus of River Godavari and described a new species of Acanthocephala (Raosentis godavarensis). Therefore, the present study was undertaken with a view to known the parasitic fauna and their probable infestation pattern in $M$. tengara in reference to sexes, length, weight and seasonal abundance.

A total of 160 live host fishes were collected on monthly basis from different fish markets of Dhaka city during March, 2012 to February, 2013. The fishes were collected in polythene bags and brought to the parasitology laboratory of Zoology department, University of Dhaka for detailed investigation. The fishes were identified, grouped according to length and weight, and sex to study the prevalence and intensity of parasite infestation. On the basis of total length (from tip of head to end of tail fin) and weight, the fish hosts were divided into three groups (viz. 7 - 9, 9.1 - 11 and 11.1 - $13 \mathrm{~cm}$ for length, and $4-8,8.1-12$ and $12.1-16 \mathrm{~g}$ for weight).

The fishes were dissected to remove the digestive tract and urinogenital organs from the body and each organ was kept into different Petri dishes. Parasites were collected from the infected organ of the host and kept in $70 \%$ ethyl alcohol. Then the parasites were mounted temporarily in lactophenol to clear the cuticle of the parasites. To make the whole mount, the worms were passed through graded series of alcohol and stained in

${ }^{1}$ Author for correspondence: Department of Zoology, Jagannath University, Dhaka-1100, Bangladesh. < subrinazool@gmail.com>. 
borax carmine. Then they were dehydrated, cleaned in xylene and mounted in Canada balsam ${ }^{(6)}$. The collected helminthes were identified with the help of figures and morphological characteristics ${ }^{(7-9)}$.

Three species of helminthes were found from the digestive tract, such as one species of trematode (Isoparorchis hypselobagrii), one species of nematode (Camallanus intestinalis) and one species of acanthocephala (Neoechinorhynchus chilkaensis). Isoparorchis hypselobagrii showed the highest prevalence $(35.63 \%)$ of infestation compared to other helminthes (Table 1). This might be due to major food items of $M$. tengara are small diatoms, small fishes, crustaceans and copepods which are the first intermediate hosts of these trematodes ${ }^{(10)}$. This feeding habit increased the possibility of ingesting food infected with many parasite species.

Out of 160 host fishes, 118 were infected with a total of 122 helminth parasites. The overall prevalence and intensity of infestation were $73.75 \%$ and 1.03 , respectively. Compared to the males the female hosts showed both highest prevalence $(75.56 \%)$ and intensity (1.05) of infestation (Table 1). Female fishes are generally more susceptible to the parasites than the males ${ }^{(11,12)}$. This might be due to lower physiological resistance, ecological habitat and sex hormones. According to Aloo et al.(13), the main reason for the differences in parasitic load with sex is physiological.

Parasitic infestation fluctuates seasonally. Overall highest prevalence $(82.72 \%)$ and intensity (1.06) were shown in rainy season and lowest in winter (Table 1). At the beginning of winter the prevalence of parasite infestation was moderate, but at the end of winter parasitic infestation was very poor. This might be due to the abundance of food in rainy season and lack of feeding tendency in winter. Moreover, the water temperature drops in winter which delays or even disrupts the development of intermediate stages of various parasites during their life cycle. This could be one of the possible reasons of low helminth infection in Mystus sp. ${ }^{(14)}$.

Host fishes were divided into three length and weight groups. The largest size group was more infected than the smaller and medium size groups (Table 2). Among three weight groups, the largest weight group was also associated with the highest percentage of infestation of parasites and lowest in the smallest weight group (Table 2). Khanum and Begum ${ }^{(12)}$ also showed highest infection in largest length and weight groups of host fishes. Bashirullah ${ }^{(2)}$ reported that the degree of parasitism was obviously related to the food habit and age of fishes.

Helminth parasites are generally found in all freshwater fishes. Prevalence and intensity of the parasite depend on many factors like parasite species and its life cycle, host and its feeding habits and the physical factors of water body where the fish inhabits. It also depends upon the presence of intermediate host, such as snails and piscivorous 
PREVALENCE AND INTENSITY OF HELMINTH PARASITES 
birds for the onward transmission of parasites infection to other hosts(15). The hygienic conditions of the water body are very important in keeping aquatic environment free from parasitic contamination.

\section{References}

1. Rakibuzzaman M and M Raknuzzaman 2011. Comparative study in endoparasitic infestation in Channa punctatus (Bloch. 1993) collected from hatchery and sewage lagoon. D.I.U J. Sci. T. 6: 6-10.

2. Bashirullah AKM 1973. A brief survey of the helminth fauna of certain marine and freshwater fishes of Bangladesh. Bangladesh J. Zool. 1: 63-81.

3. Ahmed ATA 1981. Helminth infection in freshwater fishes of Bangladesh. Fish Path. 15: 229-236.

4. Begum MM and KJ Chandra 2003. Investigation on monogenetic trematodes of Mystus vittatus, Ailiacoilaand Esomusdanricus of Mymensingh. J. Bangladesh Agril. Univ. 1(1): 87-98.

5. Vankara PG Mani and C Vijayalakshmi 2011. Metazoan parasite infracommunities of the freshwater Eel, Mastacembelus armatus Lacepede, 1800 from River Godavari, India. Int. J. Zool. Res. 7(1): 19-33.

6. Cable RM 1977. An Illustrated Laboratory Manual of Parasitology, 5th ed. Burgess Pub. Co., Miniapolis, Minnesota. pp. 165.

7. Yamaguti S 1958. Systema Helminthum Vol. I. The Trematodes of Vertebrates. Interscience Publishers Inc., New York. pp. 1-1575.

8. Yamaguti S 1959. Systema Helminthum Vol. II. The Cestodes of Vertebrates. Interscience Publishers Inc. New York. pp. 1-860.

9. Yamaguti S 1961. Systema Helminthum Vol. III. The Nematodes of Vertebrates. Interscience Publishers Inc. New York. pp. 1-423.

10. Margolis LG, W Esch, JC Holmes, AM Kuris and GA Shad 1982. The use of ecological terms in parasitology. (Report of an Ad Hoc Committee of American Society of Parasitology). J. Parasitol. 68(1): 131-133.

11. Kennedy CR and SF Lie 1974. The distribution and pathogenicity of larvae of Eustrongyllids (nematode) in brown trout Salmo trutta (L) in Feraworthy Reservoir. Devon J. Fish. Biol. 8: 293-302.

12. Khanum H, N Begum and A Begum 2008. Infestation of helminth parasites in Panna microdon (Blecker, 1849). Dhaka Univ. J. Biol. Sci. 17(1): 51-57.

13. Aloo PA, RO Anam and JN Mwangi 2004. Metazoan parasites of some commercially important fish along the Kenyan Coast. Western Indian Ocean. J. Mar. Sci. 3(1): 71-78.

14. hakir HA and AM Khan 2006. The prevalence of cestode infection in a freshwater catfish, Sperata sarwari. Punjab Univ. J. Zool. 21(1-2): 41-47.

15. Zaidi DA and D Khan 1976. Cestodes of fishes from Pakistan. Biologia (Lahore) 22: 157-179. 